\title{
Microbial Strains Employed for L-Methionine Fermentation: An Extensive Review
}

\author{
Subhadeep Ganguly, * Kunja Bihari Satapathy \\ PG Department of Botany, Utkal University, Vani Vihar, Bhubaneswar, Odisha
}

\begin{abstract}
An eco-friendly method for microbial production of L-amino acid was started in 1957 by Kinoshita and his co-workers using Micrococcus glutamicus. Since then, several trials have been done to improve Lmethionine fermentation. Different wild, auxotrophic and regulatory mutants including analog-resistantstrains were employed. Corynebacterium glutamicum, Brevibacterium sp., Lactobacilli, Bacillus heali were very common in this practice.
\end{abstract}

Keywords: Kinoshita, Micrococcus glutamicus, Corynebacterium glutamicum, Brevibacterium sp., Lactobacilli, Bacillus heali

\section{INTRODUCTION}

L-methionine is an essential amino acid required for human diet. Deficiency of this amino acid leads to several physiological disorders (such as toxemia, depression, hair loss, schizophenia, growth retardation etc.[1].These deficiencies can be overcome by supplimenting the diet with L-methionine and thus it is of significant interest.

L-methionine is produced either by: (1) Chemical synthesis or by (2) hydrolysis of proteins. These processes are expensive. In addition, chemical synthesis of L-methionine uses several toxic chemicals (such as acrolin, methyl mercaptan, ammonia, cyanide etc.) [2]. In august, 2005, a EU ordinance prohibits the use of synthesizedL-methionine for animal feed due to several toxic effects ofv different chemicals used for its production. Thus, an alternatiove, eco-friendly method for production of Lmethionine will needed to be develop.

Microbial production of different amino acids has been initiated through the isolation of Micrococcus glutamicus by Kinoshita and his collegues in 1957 for L-glutamic acid production. Since then, several microbial strains were isolated and tested for different amino acid production. The present review is intended to focus on the use of different microorganisms for the production of L-methionine.

\section{SELECTION OF SUITABLE MICROORGANISMS FOR L-METHIONINE FERMENTATION}

To successfully establish an economically viable, eco-friendly method for microbial production of Lmethionine, high yielding strains must be isolated or developed. Wild-type of strains are not capable of acuumulating huge amount of L-methionine in the fermentation broth as its biosynthesis is tightly regulated [3,4]. Unlike other fermentation pathways, L-methionine production requires ATP and therefore, its overproduction is tremendously wasteful to microorganisms and only the amount needed for their growth is produced by fermentation under normal circumstances. Corynebacterium glutamicum $\mathrm{K}$ and Brevibacterium roseum comparatively have easier regulatory mechanisms for Lmethionine production than E.coli in which almost all the enzymes are repressed by the metabolic end products [5]. Thus, it would be better to choose microorganisms with simple regulatory mechanisms for L-methionine production. In addition to Corynebacterium glutamicum $\mathrm{K}$ and Brevibacterium roseum, Lactobacilli and yiests are also widely used for the production of different amino acids [6].

Methionine is a member of aspertate family of amino acids. The pathways for the biosynthesis of these amino acids have been extensively studied [7-12]. The pathways for L-methionine fermentation in different microorganisms have many similar characteristic features, though the microorganisms employ different biosynthetic pathways. Initially, aspartate, which is converted to 4-phosphoaspartate by as aspartate kinase, then is oxidised to aspartate semi- aldehyde. It is then oxidised to homoserine by homoserine dehydrogenase. Homoserine is condensed with succinyl coA by homoserine-o- 
succinyltransferase to form o- succinyl homoserine. Some bacteria (such asd Bacillus and Corynebacterium ) produced o-acetyl homoserine instead of succinyl homoserine [13]. L-methionine formation from o- acetyl homoserine occurs via two pathways: (1) either via formation of homocysteine from cystathione or (2) via formation of homocysteine by o-acetyl homoserine (thiol)lyase [14]. The L-methionine fermentation in Brevibacterium flavum involves sulfhydrylation of oacetyl homoserine [15]. Corynebacterium glutamicum K, Corynebacterium glutamicum lactofermentum and Brevibacterium flavum exhibit both transulfuration as well as direct sulfhydrylation pathways for L-methionine biosynthesis [16].

Several auxotrophic mutants were investigated for the production of 1-methionine. L-methionineresistant mutant of Bacillus heli accumulated upto $13 \mathrm{ml} . \mathrm{L}^{-1}$ L-methionine [17]. Several L-methionine analogs are commonly used for the development of L-methionine overproducers [18-21].

Very recently, a mutant strain Lactobacillus plantarum, wild strains of Bacillus cereus, wild strain of Corynebacterium glutamicum $\mathrm{K}$, Bacillus thuringiensis $\mathrm{EC} 1$ etc are in common use for fermentative production of L-methionine [22-25].

Thus, from this present review, it can be claimed that by selecting suitable microbial strains, the production of L-methionione can be improved significantly.

\section{REFERENCES}

[1] Rose, W.C., Physiol.Rev., 18: 109-136 (1938).

[2] Tosa, T., Mori, T., Fuse, N. And Chibata, I., Biotechnol.Bioeng., 9: 603-608 (1967).

[3] Rowbury, R.J. and Woods, D.D., J.Gen.Microbial., 24: 129-144 (1961).

[4] Hermann, T., J.Biotechnol., 104: 155-172 (2003).

[5] Tosa, O. And Takinami, K., Biotechnology of amino acid production, In: Aida, K., Chibata, I. And Nakayama, K., (eds.), Progress in Industrial Microbiology, Vol.24, Elsevier: Tokyo, 1986; p.152-172.

[6] Odunfa, S.A., Adeniran, S.A. and Teniola, .D., Int.J. Food Microbiol., 63: 153-159 (2001).

[7] Stadtman, E.R., Le, B.G. and De, Robichon, J.Biol.Chem., 236: 2033-2038 (1961).

[8] Yugari, Y. And Gilvarg, C., Biochem. Biophys.Acta., 62: 612-614 (1962).

[9] Rowbury, R.J. and Woods, D.D., J.Gen.Microbial., 36: 341-358 (1964).

[10] Patte, J.C. and Bross, G.L., Biochem. Biophys.Acta., 136: 245-257(1967).

[11] Umberger, H.E., Ann.Rev. Biochem., 38: 323-349 (1969).

[12] Morinaga, Y., Tani, Y. And Yamada, H., Biosci.Biotechnol.Biochem., 60:2855-2860 (1996).

[13] Flavin, M., Metabolic sulphur compounds, In : Greenburg, D.M. (eds.), Metabolic pathways, $\mathbf{4}^{\text {th }}$ edition, Academic press: New York, 1975; p. 457-503.

[14] Kerr, D.S. and Flavin, M., J.Biol.Chem., 245: 1842-1855 (1970).

[15] Ozaki, H. and Shiio, I., J. Biol.Chem., 91: 1163-1171 (1982).

[16] Hwang, B.J. , Yeom, H.J., Kim, Y. And Lee, H.S., J.Bacteriol., 184: 1277-1286 (2002).

[17] Mondal, S., Das, Y.B. and Chatterjee, S.P., Agric.Biotechnol., 14: 61-66 (1994).

[18] Roy, S.K., Mishra, A.K. and Nanda, G., Curr.Sci., 53: 1296-1297 (1984).

[19] Kumar, D., Gang, S., Bisaria, V.S., Sreekrishnan, T.R. and Gomes, J., Process Biochem., 38: 1165-1171 (2003).

[20] Kase, H. and Nakayama, k., Agric. Biol.Chem., 39: 153-160 (1975).

[21] Nakamori, S., Kobayashi, S., Kobayashi, C. And Tagaki, H., Appl.Environ.Microbiol., 64: 16071611 (1999).

[22] Anike, N. And Okafor, N., Afr.J.Agric Nutr.Dev., 8: 77-90 (2008).

[23] Dike, K.S. and Ekwealor, I.A., Eur.J.Exp.Biol., 2: 311-314 (2008).

[24] Naryana, V.A., Vesipriya, A., Ventata N.R., Swami, A.V.N., Sumalatha, B. and Vijaya, L.M., Res.J. Pharm.Biol.Chem. Sci., 4: 1489-1497 (2013).

[25] Anakwenze ,V.N., Ezemba, C.C. and Ekwealor, I. A., Adv. Microbiol.,4; 344-352 (2014). 